\title{
PRAWNE DETERMINANTY \\ FUNKCJONOWANIA APTEK OGÓLNODOSTĘPNYCH A BEZPIECZEŃSTWO PACJENTA
}

\begin{abstract}
WSTĘP
Przyjęty model funkcjonowania aptek ogólnodostępnych determinuje przede wszystkim cel publiczny wyznaczający obowiązek zagwarantowania ochrony egzystencjalnym i przyrodzonym dobrom, jakimi są zdrowie i życie ludzkie $^{1} \mathrm{w}$ perspektywie stanu zdrowotnego jednostki, jak i niedookreślonej zbiorowości, jaką te jednostki tworzą, kiedy realizowane są cele w zakresie ochrony zdrowia publicznego ${ }^{2}$. Zdrowie ludzkie podlega ochronie na zasadzie wyrażonej w art. 68 ust. 1 i 2 Konstytucji i jest nierozerwalnie związane z prawem do ochrony życia (art. 38 Konstytucji), a tym samym z godnością człowieka (art. 30 Konstytucji) ${ }^{3}$. Zadania państwa w obszarze wyznaczonym normą art. 68 ust.1 i 2 ustawy zasadniczej powinny być skorelowane z obowiązkiem stworzenia systemu ochrony zdrowia funkcjonalnie ukierunkowanego na zwalczanie i zapobieganie chorobom. Konieczność zabezpieczenia

Dr Katarzyna MeŁgieŚ - asystent Katedry Prawa Administracyjnego, Instytut Prawa na Wydziale Prawa, Prawa Kanonicznego i Administracji Katolickiego Uniwersytetu Lubelskiego Jana Pawła II, Al. Racławickie 14, 20-950 Lublin; e-mail: katarzyna.melgies@kul.pl; ORCID: https:// orcid.org/0000-0003-2420-246X.

${ }^{1}$ Szerzej K. MeŁgieŚ, K. MiaskowsKA-DASZKIEwicZ, Zdrowie ludzkie jako wartość determinująca zadania administracji publicznej, [w:] Aksjologia prawa administracyjnego, t. I, red. J. Zimmermann, Warszawa: Wolters Kluwer 2017, s. 257.

${ }^{2}$ Zob. S. PoźDZIOCH, Prawo zdrowia publicznego, Kraków: Zdrowie i Zarządzanie 2004, s. 19; J. OPOLSKI, Zdrowie publiczne - elementy teorii, [w:] Zdrowie publiczne - wybrane zagadnienia, red. J. Opolski, Warszawa: PZWL 2011, s. 20; a także K. MeŁgIEŚ, K. MiASKOwSKA-DASZKIEwicZ, Zdrowie ludzkie jako wartość, s. 258.

${ }^{3}$ Tak TK w wyroku z dnia 7 stycznia 2004 r., K14/03.
\end{abstract}


wskazanych dóbr wynika także $\mathrm{z}$ obowiązku państwa zapewnienia bezpieczeństwa publicznego (art. 5 Konstytucji), w obszarze którego doktryna prawa specyfikuje bezpieczeństwo farmaceutyczne ${ }^{4}-$ jako komponent szerzej ujmowanego bezpieczeństwa zdrowotnego ${ }^{5}$. W tej perspektywie determinowanej przywołanymi normami konstytucyjnymi, lokować należy prawo pacjenta do bezpiecznej ochrony zdrowia ${ }^{6}$, w tym zapewnienia rzeczywistej dostępności do bezpiecznych świadczeń zdrowotnych ${ }^{7}$, obejmujących w szczególności dostęp do produktów leczniczych oraz usług i świadczeń zdrowotnych udzielanych przez apteki ogólnodostępne.

Prowadzenie apteki ogólnodostępnej to jednocześnie rodzaj aktywności gospodarczej, a właściciel apteki nie traci z racji oferowanych produktów i usług statusu przedsiębiorcy. Stąd konieczność ingerencji państwa w obszar objęty gwarancją wolności gospodarczej, statuowaną w art. 20 Konstytucji $^{8}$, w celu realizacji zadań związanych z zapewnieniem bezpieczeństwa pacjentom przy uwzględnieniu testu proporcjonalności ${ }^{9}$, wynikającego $\mathrm{z}$ art. 31 ust. 3 Konstytucji.

Jako podmioty uczestniczące zarówno w procesie dystrybucji produktów leczniczych ${ }^{10}$, jak i przy świadczeniu usług farmaceutycznych, w tym świadczeń zdrowotnych, przedsiębiorcy muszą podporządkować się całkowicie reżimowi ustalonemu $\mathrm{w}$ Prawie farmaceutycznym $\mathrm{z}$ intencjonalnym ograniczeniem swobody działalności gospodarczej ${ }^{11}$. Podkreślić należy również istotny wpływ na ich sytuację prawną regulacji wynikających z przepisów ustawy o zawodzie farmaceuty ${ }^{12}$. Słusznie podkreślał R. Stankiewicz, że utożsamianie apteki wyłącznie z przedsiębiorcą nastawionym na osiąganie

${ }^{4}$ R. STANKIEWICZ, Model racjonalizacji dostepu do produktu leczniczego. Zagadnienia publicznoprawne, Warszawa: C.H. Beck 2014, s. 11.

${ }^{5}$ Tamże.

${ }^{6}$ Zob. M. Mikos, M. UrbaniaK, Prawo do bezpiecznej ochrony zdrowia w świetle Konstytucji RP oraz rekomendacji Rady Europy i Rady Unii Europejskiej, „Medyczna Wokanda” 8 (2016), s. 166.

${ }^{7}$ Tamże, s. 162.

${ }^{8}$ Konstytucja Rzeczypospolitej Polskiej z dnia 2 kwietnia 1997 r., Dz.U. z 1997 r., Nr 78, poz. 483 z późn. zm. i sprost.

${ }^{9}$ Trybunał Konstytucyjny przeprowadza tzw. test proporcjonalności, badając łączne spełnienie trzech warunków: adekwatności (czy wprowadzone ograniczenie służy realizacji założonego celu należącego do katalogu z art. 31 ust. 3 Konstytucji), konieczności (czy jest niezbędne dla osiągnięcia tego celu) oraz proporcjonalności sensu stricto (czy nie stanowi zbyt wysokiego kosztu realizacji celu, aby spełniona została zasada proporcjonalności). Zob. wyrok TK z 28.04.2009 r., P 22/07; wyrok TK z 5.02.2008 r., K 34/06; wyrok TK z 16.10.2014 r., SK 34/06.

${ }^{10}$ Art. 2 pkt 32 ustawy z dnia 6 września 2001 r. - Prawo farmaceutyczne, Dz.U. z 2020 r., poz. 944 z późn. zm. [dalej: u.p.f.].

${ }^{11}$ Art. 63 ust. 1 u.p.f.

${ }^{12}$ Ustawa z dnia 10 grudnia 2020 r. o zawodzie farmaceuty, Dz.U. z 2021 r., poz. 97 [dalej: u.z.f.]. Ustawa weszła w życie 16 kwietnia 2021 r. 
zysku nie stanowi należytego zabiegu ${ }^{13}$. Usługi farmaceutyczne, podobnie jak świadczona w aptece opieka farmaceutyczna, powodują, że nie powinno się dopuszczać ujmowania działalności apteki ogólnodostępnej jedynie w kategoriach ekonomiczno-gospodarczych.

W konsekwencji prowadzenie apteki ogólnodostępnej uznać należy za działalność gospodarczą, która ze względu na szczególną rolę aptek-przedsiębiorstw ${ }^{14} \mathrm{w}$ systemie ochrony zdrowia została normatywnie ukierunkowana na realizację celów zdefiniowanych w zakresie opieki zdrowotnej i jednocześnie poddana specyficznym instrumentom reglamentacji ze strony organów państwa, aby umożliwić im sprawowanie nadzoru nad ich działalnością w celu zapewniania bezpieczeństwa pacjentom.

W tak zakreślonej perspektywie sformułowano pytanie, czy zastosowane rozwiązania $\mathrm{i}$ instrumenty prawne odnoszące się do funkcjonowania aptek ogólnodostępnych są wystarczające dla zapewnienia bezpieczeństwa pacjentom. Aby osiągnąć anonsowany cel niniejszego opracowania, przeprowadzona zostanie analiza funkcjonujących $w$ przestrzeni prawnej regulacji dotyczących zasad funkcjonowania aptek ogólnodostępnych, ze szczególnym uwzględnieniem zmian wynikających z ustawy o zawodzie farmaceuty.

Odpowiedź na tak postawione pytanie wymaga przede wszystkim uwzględnienia aspektu obejmującego powinność państwa w zakresie stworzenia systemowych rozwiązań urzeczywistniających prawo do bezpiecznej ochrony zdrowia, posiłkowo uwzględnić należy również nakaz spełnienia testu proporcjonalności $\mathrm{w}$ odniesieniu do wprowadzonych ograniczeń towarzyszących realizacji obowiązku w jego aspekcie pozytywnym.

\section{APTEKA OGÓLNODOSTĘPNA JAKO PLACÓWKA OCHRONY ZDROWIA PUBLICZNEGO}

Normodawca zadecydował o nadaniu aptece szczególnego statusu prawnego poprzez uznanie jej za placówkę ochrony zdrowia publicznego, w której uprawnione osoby świadczą usługi farmaceutyczne, a także za miejsce sprawowania opieki farmaceutycznej oraz wykonywania zadań zawodowych przez farmaceutów (art. 86 ust. 1 i 2 u.p.f.) ${ }^{15}$.

\footnotetext{
${ }^{13}$ R. STANKIEWICZ, Instytucje rynku farmaceutycznego, Warszawa: Wolters Kluwer 2016, s. 361.

${ }^{14}$ Zob. art. 86 ust. 1 u.p.f.; L. OGIEGŁo, Apteki, [w:] System prawa medycznego, t. IV: Prawo farmaceutyczne, red. J. Haberko, Warszawa: C.H. Beck 2019, s. 981.

${ }^{15}$ Szerzej K. MiaskowsKA-DaszKIEwICZ, Farmaceuta i technik farmaceutyczny, [w:] System prawa medycznego, t. IV, s. 60.
} 
Tak wyznaczony status nakazuje stosowanie odmiennych kryteriów oceny działalności tej kategorii przedsiębiorców, a nie jedynie ograniczanie się do kryterium zysku. Określenie apteki jako „placówki zdrowia publicznego” wskazuje, że ustawa uznaje apteki za instytucje wyższej użyteczności publicznej. Szczególna ranga aptek wynika $\mathrm{z}$ tego, że w założeniu mają one służyć nie tylko zaopatrywaniu pacjentów w różnego rodzaju produkty lecznicze, lecz także mają być miejscem, gdzie wykonywane są usługi z zakresu ochrony zdrowia ${ }^{16}$, w tym sensie winny być postrzegane w sposób zbliżony do zakładów opieki zdrowotnej ${ }^{17}$.

Ustawodawca wyróżnia trzy podstawowe typy aptek - apteki ogólnodostępne, szpitalne i zakładowe. Jakkolwiek we wszystkich farmaceuci realizują swoje ustawowo określone zadania zawodowe, to jednocześnie każdy rodzaj apteki - ze względu na miejsce usytuowania - ma swoją specyfikę i przypisaną ustawowo rolę ${ }^{18}$. Apteki ogólnodostępne ${ }^{19}$ klasyfikowane są jako podstawowe placówki ochrony zdrowia publicznego, w których dokonuje się bezpośredniego zaopatrywania ludności w produkty lecznicze, leki apteczne, leki recepturowe, wyroby medyczne i inne artykuły wskazane w ustawie, a także zapewnia świadczenie ludności usług farmaceutycznych poprzez sprawowanie opieki farmaceutycznej ${ }^{20}$.

$\mathrm{Na}$ szczególną pozycję tych placówek wskazuje ustawowe ograniczenie zawarte w art. 86 ust. 2 u.p.f., zgodnie z którym nazwa „apteka” zastrzeżona jest wyłącznie dla miejsca sprawowania opieki farmaceutycznej, świadczenia usług farmaceutycznych i wykonywania zadań zawodowych farmaceutów,

${ }^{16}$ Tak W.L. Olszewski, Komentarz do art. 86, [w:] Prawo farmaceutyczne. Komentarz, red. W. L. Olszewski, Warszawa: Wolters Kluwer 2016, s. 919.

${ }^{17}$ Tak R. STANKIEwICZ, Instytucje rynku farmaceutycznego, Warszawa 2016, s. 78, a także D. KACZAN, Świadczenie uslug farmaceutycznych jako udzielanie świadczeń zdrowotnych, „Ruch Prawniczy, Ekonomiczny i Socjologiczny” 81 (2019), nr 4, s. 152.

${ }^{18}$ Zob. art. 87 ust. 1 u.p.f. Szerzej na temat pozostałych typów aptek L. OGIEGŁO, Apteki, s. $986-990$.

${ }^{19}$ Przywoływany w dalszej części opracowania termin „apteka” bez dookreślenia jej charakteru należy odnosić do aptek ogólnodostępnych.

${ }^{20}$ Zob. art. 87 ust. 2 u.p.f. Należy zaznaczyć, że część przedstawicieli doktryny prawa utożsamia termin ,apteka” jedynie z określonym miejscem, tak L. OGIEGŁO, Komentarz do artykułu 68, [w:] Prawo farmaceutyczne. Komentarz, red. L. Ogiegło, Warszawa: C.H. Beck 2010, s. 707. Zgodzić się wszakże należy z poglądem zgłaszanym zanim wprowadzono omawiane zmiany, że nazwa ta powinna być utożsamiana nie tylko $\mathrm{z}$ określonym miejscem, ale także $\mathrm{z}$ formą dokonywanych czynności, na którą składają się: zaopatrywanie ludności w produkty i wyroby limitowane ustawą, w tym przede wszystkim produkty lecznicze, świadczenie usług farmaceutycznych oraz - co wynika z ostatniej nowelizacji - udzielanie świadczeń zdrowotnych kwalifikowanych jako opieka farmaceutyczna - tak R.J. KRUSZYŃSKI, Obrót detaliczny lekami. Zagadnienia prawne, Warszawa: Wolters Kluwers 2014, s. 53. 
pod warunkiem, że przedsiębiorca uzyska stosowne zezwolenie ${ }^{21}$. Wskazana nazwa rodzajowa została zastrzeżona dla omawianej kategorii przedsiębiorstw nie bez przyczyny, bowiem prowadzeniu aptek towarzyszy konieczność spełnienia najdalej idących wymagań w sferze organizacji danej placówki - dotyczących zarówno jej wykwalifikowanego personelu, jak i samych warunków lokalowych ${ }^{22}$. Chociaż podkreśla się, że ten szczególny przywilej nazewniczy oceniany być powinien jako uprawnienie przedsiębiorcy, a nie obowiązek jego stosowania ${ }^{23}$, to jednak uzyskanie takiego monopolu niewątpliwie służy wzmocnieniu przekonania i zaufania pacjentów korzystających $\mathrm{z}$ usług $\mathrm{w}$ tych placówkach o zagwarantowanym im przez państwo bezpieczeństwie, przede wszystkim ze względu na możliwość bycia objętym w takiej placówce opieką przez profesjonalny personel medyczny.

W tym miejscu podkreślić należy, że przypisanie aptekom statusu placówki ochrony zdrowia publicznego ma wpływ na interpretację praw i obowiązków przedsiębiorcy, zwłaszcza w zakresie rodzaju produktów i usług oferowanych w aptece oraz sposobu ich świadczenia. Wskazuje się, że apteka powinna wstrzymać się od prowadzenia inicjatyw wątpliwych pod względem ochrony zdrowia publicznego czy prowadzenia działań zmierzających do maksymalizacji zysku kosztem zdrowia publicznego ${ }^{24}$. Ponadto należy ocenić, że zmiana, jaka dokonała się $\mathrm{w}$ związku $\mathrm{z}$ wejściem $\mathrm{w}$ życie przepisów ustawy o zawodzie farmaceuty, odnosząca się do zakresu usług i świadczeń udzielanych przez apteki ogólnodostępne, potwierdziła jej rolę i zadania jako placówki ochrony zdrowia publicznego, wypełniając lukę w systemie ochrony zdrowia i odpowiadając na jego potrzeby związane z deficytami personelu medycznego oraz przeciążeniem ${ }^{25}$. Realizując postulaty samorządu zawodowego ${ }^{26}$, ustawodawca konsekwentnie wzmocnił aptekę, doprowadzając do rozszerzenia zakresu świadczeń udzielanych $\mathrm{w}$ aptekach ogólnodostępnych przez farmaceutów w taki sposób, aby mogli brać oni aktywny i znaczący udział w działaniach związanych z profilaktyką, promocją zdrowia i farmakoterapią.

\footnotetext{
${ }^{21}$ Zastrzeżenie dotyczące konieczności uzyskania zezwolenia na prowadzenie apteki co prawda nie zostało wprost wyrażone w cytowanym przepisie, ale jest oczywistą konsekwencją określenia zasad podejmowania tej reglamentowanej działalności gospodarczej.

22 I.B. NESTORUK, Nazwy rodzajowe na rynku ushg leczniczych oraz farmaceutycznych - z problematyki ochrony oznaczeń przedsiębiorstwa, „Przegląd Prawa Handlowego” 2014, nr 5 (261), s. 11.

${ }^{23}$ Tamże.

24 Tamże.

${ }^{25}$ Zob. Druk sejmowy $\mathrm{nr}$ 238, rządowy projekt ustawy o zawodzie farmaceuty, https:// www.sejm.gov.pl/Sejm9.nsf/druk.xsp?nr=238 [dostęp: 20.02.2021].

${ }^{26}$ Polityka lekowa państwa 2018-2022, https://www.gov.pl/web/zdrowie/rada-ministrow-przyjeladokument-polityka-lekowa-panstwa-20182022 [dostęp: 20.02.2021].
} 


\section{ZEZWOLENIE NA PROWADZENIE APTEKI OGÓLNODOSTĘPNEJ}

Zezwolenie na prowadzenie apteki ogólnodostępnej to instrument prawny stosowany w celu dokonania prewencyjnej weryfikacji, zmierzającej do potwierdzenia braku zagrożenia dla chronionych dóbr ${ }^{27}$. Należy zauważyć, że nie tyle sam obowiązek uzyskania zezwolenia, ile warunki determinujące udzielenie takiej zgody przez właściwy organ ${ }^{28}$ decydują o adekwatności i skuteczności zabezpieczenia relewantnych wartości. Ewolucja regulacji prawnych dotyczących przesłanek determinujących udzielenie zezwolenia na prowadzenie apteki wskazuje, że ustawodawca stale poszukuje optymalnych rozwiązań prawnych pozwalających na przeciwdziałanie negatywnym zjawiskom i zwalczanie ich w obszarze objętym bezpieczeństwem zdrowotnym pacjentów. Zmianom warunków udzielania zezwolenia poświęcono szereg publikacji ${ }^{29}$, które wskazują, że warunki te powinny być poddawane okresowej weryfikacji przede wszystkim w perspektywie aktualizujących się zagrożeń. Tradycyjnie udzielenie zezwolenia determinowało zatrudnienie odpowiednio doświadczonego farmaceuty na stanowisku kierownika apteki odpowiedzialnego za jej prowadzenie ${ }^{30}$, spełnienie warunków lokalowych gwarantujących

${ }^{27}$ D.R. KIJowsKi, Zezwolenia i koncesje, [w:] System prawa administracyjnego, t. VII: Prawo administracyjne materialne, red. R. Hauser, Z. Niewiadomski, A. Wróbel, Warszawa: C.H. Beck 2012, s. 384. Zob. też TENŻE, Pozwolenia $w$ administracji publicznej. Studium z teorii prawa administracyjnego, Białystok: Temida 2 2000, s. 198.

${ }^{28} \mathrm{~W}$ przypadku zezwoleń na prowadzenie apteki ogólnodostępnej jest to zgodnie z art. 99 ust. 2 u.p.f. wojewódzki inspektor farmaceutyczny [dalej: WIF].

${ }^{29}$ Przeglądu dokonanych na przestrzeni czasu regulacji w zakresie warunków udzielania zezwoleń na prowadzenie aptek dokonują w szczególności: L. ZACHARKO, L. JANIK, Zezwolenie na prowadzenie aptek $w$ świetle prawa farmaceutycznego, [w:] Problemy wspótczesnego ustrojodawstwa. Księa jubileuszowa prof. Bronisława Jastrzębskiego, red. J. Dobkowski, Olsztyn: Wydawnictwo Uniwersytetu Warmińsko-Mazurskiego 2007, s. 624; Ł. DuBIŃSKI, Reglamentacja działalności gospodarczej w prawie farmaceutycznym (problem prowadzenia aptek przez aptekarzy), [w:] Konstytucyjna zasada wolności gospodarczej, red. W. Szwajdler, H. Nowicki, Toruń: Towarzystwo Naukowe Organizacji i Kierownictwa 2009, s. 50-51; K. MeŁgIEś, K. MiAsKowsKA-DASZKIEwICZ, Brak sprzeczności z prawem Unii Europejskiej a jakość stanowionego prawa - refleksje na tle dyskutowanych zmian Prawa farmaceutycznego, [w:] Kryzys prawa administracyjnego?, t. I: Jakość prawa administracyjnego, red. D.R. Kijowski, A. Miruć, A. Suławko-Karetko, P.J. Suwaj, Warszawa: Wolters Kluwer 2012, s. 683; K. MEŁGIEŚ, Czy konieczne sq ograniczenia własnościowe w zakresie udzielania zezwoleń na prowadzenie aptek ogólnodostępnych?, [w:] Produkt leczniczy aktualne problemy prawne, red. K. Mełgieś, K. Miaskowska-Daszkiewicz, Warszawa: Medical Communications 2013, s. 123; A. JACEK, Przesłanki udzielania zezwolenia na prowadzenie apteki ogólnodostepnej po wejściu w życie przepisów ustawy „, apteka dla aptekarza”, „Zeszyty Naukowe Uniwersytetu Rzeszowskiego". Seria Prawnicza 23 (2018) 102, s. 38-50.

${ }^{30}$ Art. 88 u.p.f. 
bezpieczeństwo świadczonych $\mathrm{w}$ aptece $\mathrm{usług}^{31}$, brak możliwości łączenia prowadzenia apteki i jednoczesnego wykonywania zawodu lekarza lub lekarza dentysty $\mathrm{z}$ prowadzeniem apteki ${ }^{32}$. Zezwolenia nie otrzyma podmiot, który angażuje się w prowadzenie hurtowni farmaceutycznej, pośrednictwo w obrocie produktami leczniczymi lub działalność leczniczą ${ }^{33}$. Negatywną przesłankę stanowi fakt prowadzenia na terenie województwa samodzielnie lub pośrednio więcej niż $1 \%$ aptek ogólnodostępnych ${ }^{34}$. Zgodnie z warunkami obowiązującymi od 25 czerwca 2017 r. $^{35}$, zezwolenie nie zostanie wydane, jeżeli na jedną aptekę $\mathrm{w}$ danej gminie będzie przypadać średnio więcej niż 3 tys. mieszkańców, a odległość planowanej inwestycji od najbliższej apteki ogólnodostępnej będzie mniejsza niż 500 metrów. Jednocześnie ograniczony został krąg potencjalnych form prowadzenia działalności aptecznej. Aktualnie prawne dopuszczalne formy to jednoosobowa działalność, spółka jawna lub partnerska, których przedmiot działalności stanowi wyłącznie prowadzenie aptek, przy czym istotny jest wymóg posiadania statusu czynnego farmaceuty $^{36}$, zarówno przez indywidualnego przedsiębiorcę, jak i przez wszystkich wspólników lub partnerów spółki wnioskującej o wydanie zezwolenia ${ }^{37}$. Dodatkowo tak farmaceuta ubiegający się o wydanie zezwolenia, jak i kierownik apteki muszą dawać rękojmię należytego prowadzenia apteki. Wprowadzenie przywołanej regulacji ${ }^{38}$ opierało się na założeniu, że wyłącznie farmaceuta, jako właściciel apteki, może zagwarantować optymalne osiągnięcie podstawowego celu jej działania.

Projektodawcy wprowadzonych zmian podkreślali bliski związek aptekarza z prowadzoną przez niego apteką, który wzmacnia jego poczucie odpowiedzialności, niezbędny stosunek zaufania przedstawicieli innych zawodów medycznych

${ }^{31}$ Art. 97 u.p.f.

${ }^{32}$ Art. 99 ust. 4b u.p.f.

${ }^{33}$ Art. 101 pkt. 3 u.p.f. Zakaz łączenia pośrednictwa w obrocie produktami leczniczymi i wykonywania działalności leczniczej wprowadzono od dnia 1 sierpnia 2018 r. na mocy ustawy z dnia 7 czerwca 2018 r. o zmianie ustawy Prawo farmaceutyczne oraz niektórych innych ustaw (Dz.U. z 2018 r., poz. 1375).

${ }^{34}$ Art. 99 ust. 3 pkt. 1 i 2 u.p.f.

${ }^{35}$ Ustawa z 7 kwietnia 2017 r. o zmianie ustawy - Prawo farmaceutyczne (Dz.U. z 2017 r., poz. 1015). Na powody wprowadzenia zmiany warunków udzielania zezwoleń wskazuje w szczególności uzasadnienie do druku sejmowego nr 1126, dhttp://www.sejm.gov.pl/Sejm8.nsf/druk.xsp?nr=1126 [dostęp: 20.02.2021], a także A. JACEK, Przestanki udzielania zezwolenia, s. 38-39.

${ }^{36}$ Warunki determinujące przyznanie prawa wykonywania zawodu farmaceuty określa art. 13 u.z.f.

${ }^{37}$ Art. art. 99 ust. 4 u.p.f. wprowadzony na mocy art. 1 pkt b ustawy z 7 kwietnia 2017 r.

${ }^{38}$ Jest ona wynikiem nowelizacji Prawa farmaceutycznego, która dokonała się na mocy ustawy z dnia 7 kwietnia 2017 r. o zmianie ustawy - Prawo farmaceutyczne, Dz.U. z 2017 r., poz. 1015, i obowiązuje od dnia 25 czerwca 2017 r. 
i pacjenta oraz gwarantuje optymalne zaopatrzenie w produkty lecznicze ${ }^{39}$. Właściwy WIF odmówi wydania zezwolenia podmiotowi posiadającemu bezpośrednio lub pośrednio (poprzez podmioty kontrolowane albo spółki, w których jest wspólnikiem) cztery lub więcej aptek ${ }^{40}$. Co jest również doniosłe w perspektywie gwarancji bezpieczeństwa, przeszkodą do uzyskania zezwolenia są popełnione w przeszłości ustawowo określone delikty lub przestępstwa, uzasadniające $\mathrm{w}$ istocie brak dawania szeroko pojętej rękojmi prowadzenia obrotu produktami leczniczymi zgodnie z zakładanymi standardami ${ }^{41}$.

Podkreślić należy, że warunki podlegające weryfikacji przed rozpoczęciem działalności mają stanowić niezbędne minimum gwarancji na czas działalności apteki. Zaanonsowane rozwiązania wraz z istotnie ograniczoną sukcesją uprawnień wynikających z udzielonego zezwolenia ${ }^{42}$ oraz rygorystycznie wyznaczonymi zasadami funkcjonowania aptek ogólnodostępnych, to dalsze intencjonalne zabiegi ustawodawcy determinowane potrzebą zapewnienia bezpieczeństwa pacjentów. Aktualnie wiążące regulacje należy ocenić jako adekwatne i konieczne dla osiągnięcia tak wyznaczonego celu, a proporcjonalność ograniczenia wolności gospodarczej usprawiedliwia przede wszystkim szczególny charakter dóbr, jakimi są zdrowie i życie ludzkie.

\section{ZASADY DZIAŁALNOŚCI APTEK OGÓLNODOSTĘPNYCH I NADZÓR NAD ICH PRZESTRZEGANIEM}

Zakres dozwolonej działalności aptek został normatywnie wyznaczony w sposób bezwzględny. Przedmiot i cel ich działalności ustawodawca wyznacza w trzech podstawowych kierunkach: po pierwsze - jako zaopatrywanie ludności w produkty lecznicze, leki apteczne, leki recepturowe, wyroby medyczne i inne artykuły ujęte w zamkniętym ustawowym katalogu precyzowanym przez art. 86 ust. 8 u.p.f., po drugie - zapewnienie świadczenia ludności usług farmaceutycznych, po trzecie - sprawowanie opieki farmaceutycznej ${ }^{43}$. Ponadto mogą być $\mathrm{w}$ nich świadczone usługi związane $\mathrm{z}$ ochroną zdrowia obejmujące: monitorowanie procesu leczenia farmakologicznego stałych pacjentów apteki oraz doradztwo w samolecznictwie farmakologicznym pacjentów opierające się na pro-

\footnotetext{
${ }^{39}$ Uzasadnienie do druku sejmowego nr 1126, Sejmu VII Kadencji, Druk nr 1126, https:// www.sejm.gov.pl/Sejm8.nsf/druk.xsp?nr=1126 [dostęp: 20.02.2021].

${ }^{40}$ Art. 99 ust. 3a u.p.f.

${ }^{41}$ Art. 101 pkt 4,5 i 7 u.p.f.

42 Art. 99 ust. $2 \mathrm{a}$ i art. 104 u.p.f.

${ }^{43}$ Zob. art. 87 ust. 2 u.p.f.
} 
duktach wydawanych bez recepty (art. 86 ust. 2 b u.p.f.). Podstawowym gwarantem bezpieczeństwa pacjentów jest wymóg zatrudnienia przy wykonywaniu czynności fachowych wyłącznie farmaceutów i techników farmaceutycznych $\mathrm{w}$ granicach ich uprawnień zawodowych ${ }^{44}$. Uprawnienia zawodowe farmaceutów determinują przepisy ustawy o zawodzie farmaceuty, podczas gdy uprawnienia technika farmaceutycznego określa art. 91 u.p.f. Należy również dodać, że wprowadzono całkowity zakaz reklamy aptek oraz ich działalności, co zasadniczo motywowano koniecznością zwiększenia ochrony pacjentów i finansów publicznych przed ujemnymi skutkami takiej formy promocji aptek i ich oferty ${ }^{45}$.

Najważniejszym zadaniem aptek jest zaopatrywanie ludności w produkty lecznicze i wyroby medyczne realizowane $\mathrm{w}$ formie stacjonarnej $\mathrm{z}$ prawnie aprobowaną sprzedażą wysyłkową, w granicach art. 68 ust. 3 u.p.f. Detaliczny kanał podstawowej dystrybucji obejmuje zaopatrywanie ludności w produkty lecznicze, w tym leki apteczne ${ }^{46}$, leki recepturowe ${ }^{47}$ oraz wyroby medyczne i inne określone wyczerpująco posiadające stosowne atesty lub zezwolenia, które można sprzedawać jedynie w wydzielonych stanowiskach, „pod warunkiem że ich przechowywanie i sprzedaż nie będą przeszkadzać podstawowej działalności apteki”.

Sprzedaż produktów leczniczych oferowanych przez apteki powinna być realizowana zgodnie z modelem dystrybucji, który zakłada, że apteka zasadniczo może je zbywać wyłącznie w celu bezpośredniego zaopatrywania ludności lub podmiotowi wykonującemu działalność leczniczą. Odrębnej zgody wymaga ich przekazywanie domom pomocy społecznej oraz organom władzy publicznej w stanach nadzwyczajnych ${ }^{48}$.

Oprócz wzmiankowanych ograniczeń w dystrybucji, wskazać należy podstawowe nakazy: posiadania produktów leczniczych i wyrobów medycznych $\mathrm{w}$ ilości i asortymencie niezbędnym do zaspokojenia potrzeb zdrowotnych miejscowej ludności ${ }^{49}$, a także raportowania danych do Zintegrowanego Systemu Monitorowania Obrotu Produktami Leczniczymi ${ }^{50}$. Wprowadzone

\footnotetext{
${ }^{44}$ Art. 90 u.p.f.

${ }^{45}$ J. WISZNIEWSKA, Zakaz reklamy aptek i ich działalności - geneza wprowadzenia i ocena regulacji, „Internetowy Kwartalnik Antymonopolowy i Regulacyjny” 8 (2016), nr 5, s. 20-33; A. RABIEGA-PRZYŁĘCKA, Zakaz reklamy aptek $w$ świetle art. 94a Prawa farmaceutycznego, „Przegląd Prawa Publicznego" 2013, nr 11, s. 68-77.

${ }^{46}$ Art. 2 pkt 10 u.p.f.

${ }^{47}$ Art. 2 pkt 12 u.p.f.

${ }^{48}$ Art. 86 a ust. 1 i 3 u.p.f.

${ }^{49}$ Art. 95 ust. 1 u.p.f.

${ }^{50}$ Art. 95a u.p.f.
} 
regulacje mają służyć zapewnieniu dostępności produktów leczniczych dla pacjentów i ograniczeniu możliwości wykonywania transakcji wyłącznie opierających się na kryterium zysku z innymi podmiotami.

Nie wprowadzono ustawowej definicji pojęcia usługi farmaceutycznej, stąd trzeba zgodzić się z poglądem, że są to usługi związane $\mathrm{z}$ ochroną zdrowia, należące do kompetencji farmaceutów, które ze względu na rolę apteki jako placówki ochrony zdrowia publicznego mogą być wykonywane przez te osoby $\mathrm{w}$ aptekach ${ }^{51}$. Zostały one wyszczególnione w katalogu zawartym w art. 4 ust. 3 u.z.f. Cechą wspólną większości usług zawartych w przywołanym katalogu jest to, że do poprawnego wykonywania ich potrzebna jest pogłębiona, profesjonalna wiedza z zakresu nauk farmaceutycznych (m.in. umiejętność przeprowadzania wywiadu farmaceutycznego, znajomość skutków zdrowotnych stosowania, zasad przechowywania i oceny jakości produktów leczniczych) oraz umiejętności niezbędne do prawidłowego sporządzania leków aptecznych i recepturowych. Założenie powyższe ma również służyć bezpieczeństwu pacjenta.

Najczęściej wykonywaną usługą farmaceutyczną jest wydawanie produktów leczniczych oraz wyrobów medycznych. Usługa ta powinna być realizowana przy zapewnieniu pacjentowi gwarancji bezpieczeństwa, a służą temu przyjęte rozwiązania prawne. W tym miejscu należy przywołać te, które wprowadzają zróżnicowane kategorie dostępności produktów leczniczych determinujące swobodę działania farmaceuty oraz ustawowy obowiązek farmaceuty odmowy wydania leku przy aktualizacji ustawowo określonych przesłanek świadczących, że jego przyjęcie mogłoby zagrażać zdrowiu lub życiu pacjenta $^{52}$.

Podkreślić należy, że wyrazem troski o dobro pacjenta jest generalne uprawnienie przyznane farmaceutom, polegające na odmowie realizacji każdej usługi farmaceutycznej, jeżeli jej wykonanie może zagrażać zdrowiu lub życiu pacjenta ${ }^{53}$.

Opieka farmaceutyczna ${ }^{54} \mathrm{w}$ nowym znaczeniu nadanym temu pojęciu przez art. 4 ust. 2 u.z.f., to działania obejmujące ustawowo wyszczególnione

${ }^{51}$ Zob. W.L. OLSZEWSKI, Komentarz do art. 86, s. 921.

${ }^{52}$ Art. 96 ust. 5 pkt 2 u.p.f.

${ }^{53}$ Art. 96 ust. 5 pkt 1 u.p.f.

${ }^{54}$ W 2007 r. Naczelna Rada Aptekarska przyjęła strategię opieki farmaceutycznej w Polsce jako oficjalne stanowisko samorządu aptekarskiego, http://managerapteki.pl/model-opieki-farmaceutycznej/ [dostęp: 20.02.2021]. Pojęcie to zostało wprowadzone w art. 2a ust. 1 pkt 7 ustawy z dnia 19 kwietnia 1991 r. o izbach aptekarskich, uznając je za rodzaj usług farmaceutycznych. Szerzej M. OżóG, System handlu produktem leczniczym i produktami pokrewnymi. Problematyka prawna, Warszawa: LexisNexis 2010, s. 362 n.; K. ŻAK, Implementacja programu opieki farmaceutycznej $w$ aptece 
czynności stanowiące złożony udokumentowany proces, w którym farmaceuta, współpracując z pacjentem i lekarzem prowadzącym leczenie pacjenta, a $\mathrm{w}$ razie potrzeby z przedstawicielami innych zawodów medycznych, czuwa nad prawidłowym przebiegiem indywidualnej farmakoterapii. Katalog świadczeń zdrowotnych polegających na udzielaniu opieki farmaceutycznej sprawowanej przez farmaceutów obejmuje m.in. prowadzenie konsultacji farmaceutycznych, wykonywanie przeglądów lekowych wraz z oceną farmakoterapii, opracowywanie indywidualnego planu opieki farmaceutycznej, z uwzględnieniem problemów lekowych pacjenta, wykonywanie badań diagnostycznych w celu oceny skuteczności i bezpieczeństwa stosowanej przez pacjenta farmakoterapii oraz analizy problemów lekowych występujących $\mathrm{u}$ pacjenta czy wystawianie recept $\mathrm{w}$ ramach kontynuacji zlecenia lekarskiego ${ }^{55}$. Opieka farmaceutyczna została wyraźnie odseparowana od pojęcia usług farmaceutycznych i expressis verbis uznana za świadczenie zdrowotne ${ }^{56}$ udzielane przez farmaceutę, które powinno być odnoszone do podejmowanych względem pacjenta czynności wykonywanych właściwymi środkami i metodami mającymi służyć zachowaniu lub poprawie jego stanu zdrowia ${ }^{57}$, stanowiąc element opieki medycznej ${ }^{58}$. Dzięki jej wprowadzeniu zwiększają się możliwości poprawy jakości dystrybucji leków, racjonalnego nimi gospodarowania oraz zapewnienia prawidłowego i bezpiecznego ich stosowania w celu osiągnięcia maksymalnej skuteczności przy ograniczeniu niekorzystnych efektów polekowych. Zakwalifikowanie opieki farmaceutycznej do kategorii świadczeń zdrowotnych ma tę konsekwencję, że do aptek mają zastosowanie przepisy ustawy o prawach pacjenta ${ }^{59}$. W konsekwencji opieka farmaceutyczna powinna być udzielana z należytą starannością ${ }^{60}$ oraz zachowaniem prawa do uzyskania odpowiedniej jakości świadczenia ${ }^{61}$. Ich gwa-

ogólnodostęnej - dostosowanie do potrzeb osób niepetnosprawnych, „Ekonomia - Wroclaw Economic Review” 23 (2017), nr 1, s. 83-103; K. JASIŃSKA, Zakaz reklamy aptek a opieka farmaceutyczna i programy lojalnościowe, „Zeszyty Naukowe Uniwersytetu Jagiellońskiego. Prace z Prawa Własności Intelektualnej” 13 (2015), nr 4, s. 108-121.

${ }^{55}$ Art. 4 ust. 2 u.z.w.

${ }^{56} \mathrm{~W}$ rozumieniu art. 5 pkt 40 ustawy z dnia 27 sierpnia 2004 r. o świadczeniach opieki zdrowotnej finansowanych ze środków publicznych, Dz.U. z 2020 r., poz. 1398 z późn. zm.

${ }^{57}$ L. BoSEK, B. JANISZEWSKA, Pojęcie i podstawy prawne szczególnych świadczeń zdrowotnych, [w:] System prawa medycznego, t. II: Szczególne świadczenia zdrowotne, red. L. Bosek, A. Wnukiewicz-Kozłowska, Warszawa: C.H. Beck 2018, s. 3.

${ }^{58}$ Sejm RP VI kadencji, Druk sejmowy nr 82.

${ }^{59}$ Art. 2 ustawy z dnia 6 listopada 2008 r. o prawach pacjenta i Rzeczniku Praw Pacjenta, t.j. Dz.U. z 2020 r., poz. 849 z późn. zm. [dalej: u.p.p.].

${ }^{60}$ Art. 8 u.p.p.

${ }^{61}$ Art. 6 u.p.p. 
rantem jest Rzecznik Praw Pacjenta ${ }^{62}$, który w szczególności został uprawniony do inicjowania postępowań w sprawach naruszających zarówno indywidualne, jak i zbiorowe prawa pacjentów, także w przypadku, gdy deliktu dopuszcza się personel apteki.

Zapewnieniu bezpieczeństwa pacjentów służy obowiązek farmaceuty ${ }^{63}$ udzielania pełnej i przystępnej informacji o lekach, ich działaniu, stosowaniu, środkach ostrożności i ewentualnych interakcjach, a także o zasadach ich przechowywania i utylizacji. W tym miejscu należy również przywołać gwarancje bezpieczeństwa wynikające ze standardów sprawowania opieki farmaceutycznej zawartych w zasadach Kodeksu Etyki Aptekarza ${ }^{64}$.

Na skutek zmian wynikających z ustawy o zawodzie farmaceuty ustawodawca znacząco wzmocnił jego samodzielność przy podejmowaniu decyzji w zakresie sprawowania opieki farmaceutycznej, udzielania usług farmaceutycznych oraz wykonywania zadań zawodowych, wprowadzając dyrektywę postępowania, zgodnie z którą farmaceuta ma kierować się wyłącznie dobrem pacjenta oraz nie może być tu związany z poleceniem służbowym ${ }^{65}$.

Poprzez stałe monitorowanie bieżącej działalności aptek dotyczącej obrotu produktami leczniczymi i wyrobami medycznymi, wyspecjalizowane organy inspekcji i kontroli Państwowej Inspekcji Farmaceutycznej sprawują nadzór $\mathrm{w}$ celu zabezpieczenia interesu społecznego $\mathrm{w}$ zakresie bezpieczeństwa zdrowia i życia ludzi przy stosowaniu produktów leczniczych i wyrobów medycznych ${ }^{66}$. Kontroli tej podlegają zarówno czynności obrotu, jak i jakość znajdujących się tam produktów leczniczych i wyrobów medycznych. Naruszanie przez aptekę ustawowych obowiązków nałożonych ze względu na potrzebę zapewniania bezpieczeństwa pacjentów aktualizuje obowiązek zastosowania sankcji administracyjnych $\mathrm{w}$ postaci cofnięcia zezwolenia na prowadzenie apteki ${ }^{67}$ czy nałożenia kary pieniężnej ${ }^{68}$ lub wymierzenia sankcji karnych ${ }^{69}$.

${ }^{62}$ Art. 41 u.p.p.

${ }^{63}$ Art. 28 u.p.f.

${ }^{64}$ Kodeks Etyki Aptekarza Rzeczypospolitej Polskiej, https://www.nia.org.pl/kodeks-etyki/ [dostęp: 10.04.2021]. Obszernie K. MIASKOWSKA-DASZKIEWICZ, Standardy wykonywania zawodu farmaceuty zatrudnionego $w$ aptece ogólnodostępnej, [w:] Standard wykonywania zawodów medycznych, red. A. Górski, E. Sarnacka, M. Grassmann, Warszawa: C.H. Beck 2019, s. 150 n.

${ }^{65}$ Podmiot prowadzący aptekę ogólnodostępną ma obowiązek umożliwić aptekarzowi samodzielne podejmowanie decyzji w zakresie sprawowania opieki farmaceutycznej, udzielania usług farmaceutycznych lub wykonywania zadań zawodowych w zakresie, w jakim są one związane z prowadzoną przez ten podmiot działalnością. Niewykonanie tego obowiązku jest podstawą do fakultatywnego cofnięcia zezwolenia na prowadzenie apteki - art. 103 ust. 2 u.p.f. w zw. $\mathrm{z}$ art. 32 ust. 2 u.z.f.

${ }^{66}$ Zob. art. 108 ust. 1 u.p.f.

${ }^{67}$ Art. 103 u.p.f.

${ }^{68}$ Art. 127 u.p.f., art. 129 b u.p.f., art. 129 d u.p.f., art. 129e u.p.f. 
Sprawowanie pieczy i nadzoru nad wykonywaniem zawodu farmaceuty powierzone zostało samorządowi zawodu farmaceuty ${ }^{70}$. Wprowadzone regulacje zawierają m.in. sankcje za działania niezgodne z zasadami wykonywania zawodu farmaceuty oraz etyki i deontologii zawodowej ${ }^{71}$, przejawiające się w uprawnieniu do nakładania kary upomnienia i nagany oraz zawieszenia lub pozbawiania prawa wykonywania zawodu ${ }^{72}$.

\section{WNIOSKI}

Poddając analizie rozwiązania prawne odnoszące się do funkcjonowania aptek $\mathrm{w}$ perspektywie zapewniania bezpieczeństwa pacjentom, stwierdzić należy, że ustawodawca posłużył się zróżnicowanymi instrumentami prawnymi pozwalającymi na realizację przypisanych mu zadań.

Zakres ingerencji o charakterze reglamentacyjnym w działalność gospodarczą przedsiębiorców uznać należy za usprawiedliwiony w perspektywie testu proporcjonalności, a także za wystarczająco zabezpieczający chronione dobra, zarówno w perspektywie indywidualnej, jak i zbiorowej. Podkreślić należy, że uregulowania te odnoszą się zasadniczo do zapewnienia pacjentom dostępności produktów leczniczych należytej jakości. Ponadto, w optyce bezpieczeństwa zdrowotnego pacjenta wzrosła dostępność do usług i opieki farmaceutycznej z instytucjonalnie zagwarantowaną ochroną pacjenta, polegającą na zapewnieniu fachowości personelu apteki. Mają one kluczowe znaczenie dla zapewnienia bezpieczeństwa pacjenta, gwarantując, że pacjent w systemie ochrony zdrowia będzie się spotykać z osobami, których wiedza i umiejętności zawodowe oraz poszanowanie zasad deontologii dają należytą rękojmię.

Wskazać można jednak obszary, w których bezpieczeństwo pacjentów nie zostało zagwarantowane na odpowiednim poziomie. Wynika to z braku precyzyjnej regulacji określającej zasady świadczenia opieki farmaceutycznej, m.in. zasad współpracy z przedstawicielami innych zawodów medycznych, w szczególności z lekarzem prowadzącym pacjenta, w stosunku do którego podejmowana jest opieka. Ponadto, co do opieki farmaceutycznej obejmującej

\footnotetext{
${ }^{69}$ Art. 124 u.p.f., art. 126 u.p.f., art. 126b u.p.f.

${ }^{70}$ Samorząd stanowią: Naczelna Izba Aptekarska i okręgowe izby aptekarskie - Art. 1 ustawy z dnia 19 kwietnia 1991 r. o izbach aptekarskich, t.j. Dz.U. z 2019 r., poz. 1419 ze zm. [dalej: u.i.a.].

${ }^{71}$ Art. 45 u.i.a.

${ }^{72}$ Art. 46 ust. 1 u.i.a.
} 
szereg interwencji, które mają zapewnić prawidłowy przebieg leczenia pacjenta, to wciąż nie wprowadzono konieczności objęcia farmaceutów obowiązkowym ubezpieczeniem od odpowiedzialności cywilnej za udzielane świadczenia i wykonywane usługi.

Zwrócić należy przy tym uwagę, że nie każda apteka musi świadczyć opiekę farmaceutyczną, tym samym nie ma pewności, czy dostęp do niej będzie miał charakter powszechny, co w perspektywie zagwarantowania powszechnego dostępu do świadczeń zdrowotnych ma istotne znaczenie.

W istocie wskazane wątpliwości co do gwarancji bezpieczeństwa pacjenta dotyczące udzielania usług oraz opieki farmaceutycznej w aptekach pojawiają się przede wszystkim w związku z tym, że aktualnie brak systemowych rozwiązań służących wdrożeniu usług i opieki farmaceutycznej w wymiarze, jaki nadała im ustawa o zawodzie farmaceuty. Kluczowe pozostaje również pytanie o poziom ich finansowania przez Narodowy Fundusz Zdrowia ${ }^{73}$, co ma istotne znaczenie w perspektywie zapewnienia równej dostępności do świadczeń opieki zdrowotnej ${ }^{74}$.

Dokonując sumowania przeprowadzonych rozważań, należy stwierdzić, że jakkolwiek wskazać można pewne deficyty związane przede wszystkim z brakiem pełnego i systemowego wdrożenia zasad udzielania opieki farmaceutycznej, to synergia wszystkich wymienionych czynników prawnych, w tym zwłaszcza tych, które determinują warunki uzyskania zezwolenia aptecznego i zasad funkcjonowania aptek, daje efekt w postaci zapewnienia bezpieczeństwa pacjentów jako adresatów usług i opieki farmaceutycznej, przy uwzględnianiu testu proporcjonalności wykonanego w odniesieniu do ograniczeń wolności gospodarczej.

${ }^{73}$ Zob. Raport Opieka farmaceutyczna. Kompleksowa analiza procesu wdrożenia. Raport z prac zespołu ds. opieki farmaceutycznej powołanego przez Ministra Zdrowia na podstawie zarządzenia z dnia 8 lipca 2020 r. Dziennik Urzędowy Ministra Zdrowia z dnia 9 lipca 2020 r., https://www.gov.pl/ web/zdrowie/opieka-farmaceutyczna---raport [dostęp: 10.04.2021].

${ }^{74}$ Szerzej na temat wpływu zasad i sposobu finansowania świadczeń zdrowotnych na bezpieczeństwo pacjenta: J. PACIAN, A. PACIAN, Bezpieczeństwo pacjentów w systemie ochrony zdrowia, [w:] Wspótczesne zagrożenia bezpieczeństwa państwa, red. W. Lis, Lublin: Wydawnictwo KUL 2015, s. 276. 


\section{BIBLIOGRAFIA}

\section{ŹRÓDŁA PRAWA}

Konstytucja Rzeczypospolitej Polskiej z dnia 2 kwietnia 1997 r., Dz.U. z 1997 r., Nr 78, poz. 483 z późn. $z m$.

Ustawa z dnia 19 kwietnia 1991 r. o izbach aptekarskich, t.j. Dz.U. z 2019 r., poz. 1419 z późn. zm.

Ustawa z dnia 6 września 2001 r. - Prawo farmaceutyczne, t.j. Dz.U. z 2020 r., poz. 944 z późn. zm.

Ustawa z dnia 6 listopada 2008 r. o prawach pacjenta i Rzeczniku Praw Pacjenta, t.j. Dz.U. z 2020 r., poz. 849 z późn. zm.

Ustawa z dnia 7 kwietnia 2017 r. o zmianie ustawy - Prawo farmaceutyczne, Dz.U. z 2017 r., poz. 1015.

Ustawa $\mathrm{z}$ dnia ustawa z dnia 7 czerwca 2018 r. o zmianie ustawy Prawo farmaceutyczne oraz niektórych innych ustaw, Dz.U. z 2018 r., poz. 1375.

Ustawa z dnia 10 grudnia 2020 r. o zawodzie farmaceuty, Dz.U. z 2021 r., poz. 97.

Rozporządzenie z dnia 12 października 2018 r. w sprawie zapotrzebowań oraz wydawania z apteki produktów leczniczych, środków spożywczych specjalnego przeznaczenia żywieniowego i wyrobów medycznych, Dz.U. z 2018 r., poz. 2008.

Kodeks Etyki Aptekarza Rzeczypospolitej Polskiej, https://www.nia.org.pl/kodeks-etyki/ [dostęp: 10.04.2021].

\section{LITERATURA}

BoSEK Leszek, JANISZEWSKA Beata: Pojęcie i podstawy prawne szczególnych świadczeń zdrowotnych, [w:] System prawa medycznego, t. II: Szczególne świadczenia zdrowotne, red. Leszek Bosek, Agata Wnukiewicz-Kozłowska, Warszawa: C.H. Beck 2018, s. 1-44.

DUBIŃSKI Łukasz: Reglamentacja działalności gospodarczej w prawie farmaceutycznym (problem prowadzenia aptek przez aptekarzy), [w:] Konstytucyjna zasada wolności gospodarczej, red. Wojciech Szwajdler, Henryk Nowicki, Toruń: Towarzystwo Naukowe Organizacji i Kierownictwa 2009, s. 45-64.

JACEK Anna: Przesłanki udzielania zezwolenia na prowadzenie apteki ogólnodostępnej po wejściu w życie przepisów ustawy ,,apteka dla aptekarza”, „Zeszyty Naukowe Uniwersytetu Rzeszowskiego". Seria Prawnicza 23 (2018) 102, s. 38-50.

JASIŃSKA Katarzyna: Zakaz reklamy aptek a opieka farmaceutyczna i programy lojalnościowe, „Zeszyty Naukowe Uniwersytetu Jagiellońskiego. Prace z Prawa Własności Intelektualnej” 13 (2015), nr 4, s. 108-121.

KACZAN Damian: Świadczenie usług farmaceutycznych jako udzielanie świadczeń zdrowotnych, „Ruch Prawniczy, Ekonomiczny i Socjologiczny” 81 (2019), nr 4, s. 151-163.

KIJOwski Dariusz Ryszard: Pozwolenia w administracji publicznej. Studium z teorii prawa administracyjnego, Białystok: Temida 22000.

KIJOwsKi Dariusz Ryszard: Zezwolenia i koncesje, [w:] System prawa administracyjnego, t. VII: Prawo administracyjne materialne, red. Roman Hauser, Zygmunt Niewiadomski, Andrzej Wróbel, Warszawa: C.H. Beck 2017, s. 407-426. 
KRUSZYŃSKI Rafał Jerzy: Obrót detaliczny lekami. Zagadnienia prawne, Warszawa: Wolters Kluwers 2014.

MEŁgIEŚ Katarzyna: Czy konieczne są ograniczenia własnościowe w zakresie udzielania zezwoleń na prowadzenie aptek ogólnodostępnych?, [w:] Produkt leczniczy - aktualne problemy prawne, red. Katarzyna Mełgieś, Katarzyna Miaskowska-Daszkiewicz, Warszawa: Medical Communications 2013, s.123-139.

MeŁgieś Katarzyna, MiaskowsKA-DAszKIEwicz Katarzyna: Brak sprzeczności z prawem Unii Europejskiej a jakość stanowionego prawa - refleksje na tle dyskutowanych zmian Prawa farmaceutycznego, [w:] Kryzys prawa administracyjnego?, t. I: Jakość prawa administracyjnego, red. Dariusz R. Kijowski, Alina Miruć, Agnieszka Suławko-Karetko, Patrycja J. Suwaj, Warszawa: Wolters Kluwer 2012, s. 683-701.

MeŁgieś Katarzyna, MiaskowsKA-DAszKiewicz Katarzyna: Zdrowie ludzkie jako wartość determinująca zadania administracji publicznej, [w:] Aksjologia prawa administracyjnego, t. I, red. Jan Zimmermann, Warszawa: Wolters Kluwer 2017, s. 257-272.

MiAsKowSKA-DASZKIEwICZ Katarzyna: Farmaceuta i technik farmaceutyczny, [w:] System prawa medycznego, t. IV: Prawo farmaceutyczne, red. Joanna Haberko, Warszawa: C.H. Beck 2019, s. 35-96.

MiASKOWSKA-DASZKIEWICZ Katarzyna: Standardy wykonywania zawodu farmaceuty zatrudnionego w aptece ogólnodostępnej, [w:] Standard wykonywania zawodów medycznych, red. Adam Górski, Emilia Sarnacka, Magdalena Grassmann, Warszawa: C.H. Beck 2019, s. 149-172.

MiKos Marcin, URBANIAK Monika: Prawo do bezpiecznej ochrony zdrowia w świetle Konstytucji RP oraz rekomendacji Rady Europy i Rady Unii Europejskiej, „Medyczna Wokanda” 8 (2016), s. $159-167$.

NESTORUK Igor B.: Nazwy rodzajowe na rynku usług leczniczych oraz farmaceutycznych - z problematyki ochrony oznaczeń przedsiębiorstwa, „Przegląd Prawa Handlowego” 2014, nr 5 (261), s. $10-17$.

OPOLSKI Janusz: Zdrowie publiczne - elementy teorii, [w:] Zdrowie publiczne - wybrane zagadnienia, red. Janusz Opolski, Warszawa: PZWL2011.

OżóG Marcin: System handlu produktem leczniczym i produktami pokrewnymi. Problematyka prawna, Warszawa: LexisNexis 2010.

PACIAN Jolanta, PACIAN Anna: Bezpieczeństwo pacjentów w systemie ochrony zdrowia, [w:] Współczesne zagrożenia bezpieczeństwa państwa, red. Wojciech Lis, Lublin: Wydawnictwo KUL 2015, s. 275-286.

Polityka lekowa państwa 2018-2022, https:/www.gov.pl/web/zdrowie/rada-ministrow-przyjeladokument-polityka-lekowa-panstwa-20182022 [dostęp: 20.02.2021].

Prawo farmaceutyczne. Komentarz, red. Leszek Ogiegło, Warszawa: C.H. Beck 2010.

PoźDZıOCH Sławomir: Prawo zdrowia publicznego, Kraków: Zdrowie i Zarządzanie 2004.

RABIEGA-PRZYŁĘCKA Agnieszka: Zakaz reklamy aptek w świetle art. 94a Prawa farmaceutycznego, „Przegląd Prawa Publicznego” 2013, nr 11, s. 68-77.

Raport Opieka farmaceutyczna. Kompleksowa analiza procesu wdrożenia. Raport z prac zespołu ds. opieki farmaceutycznej powołanego przez Ministra Zdrowia na podstawie zarządzenia $\mathrm{z}$ dnia 8 lipca 2020 r. Dziennik Urzędowy Ministra Zdrowia z dnia 9 lipca 2020 r., https://www.gov.pl /web/zdrowie/opieka-farmaceutyczna---raport [dostęp: 10.04.2021]. 
STANKIEWICZ Rafał: Instytucje rynku farmaceutycznego, Warszawa: Wolters Kluwer 2016.

STANKIEWICZ Rafał: Model racjonalizacji dostępu do produktu leczniczego. Zagadnienia publicznoprawne, Warszawa: C.H. Beck 2014.

WISZNIEWSKA Joanna: Zakaz reklamy aptek i ich działalności - geneza wprowadzenia i ocena regulacji, „Internetowy Kwartalnik Antymonopolowy i Regulacyjny” 8 (2016), nr 5, s. 20-33.

ZACHARKO Lidia, JANIK Leszek: Zezwolenie na prowadzenie aptek w świetle prawa farmaceutycznego, [w:] Problemy współczesnego ustrojodawstwa. Księga jubileuszowa prof. Bronisława Jastrzębowskiego, red. Jarosław Dobkowski, Olsztyn: Wydawnictwo Uniwersytetu Warmińsko-Mazurskiego 2007, s. 624-633.

ŻAK Krzysztof: Implementacja programu opieki farmaceutycznej w aptece ogólnodostępnej dostosowanie do potrzeb osób niepełnosprawnych, „Ekonomia - Wroclaw Economic Review” 23 (2017), nr 1, s. 83-103.

\title{
PRAWNE DETERMINANTY FUNKCJONOWANIA APTEK OGÓLNODOSTĘPNYCH A BEZPIECZEŃSTWO PACJENTA
}

\author{
Streszczenie
}

Nadanie aptece szczególnego statusu prawnego poprzez uznanie jej za placówkę ochrony zdrowia publicznego, w której osoby uprawnione świadczą usługi farmaceutyczne, a także za miejsce sprawowania opieki farmaceutycznej oraz wykonywania zadań zawodowych przez farmaceutów, sytuuje to przedsiębiorstwo w sferze istotnego oddziaływania państwa i jego organów. Nakazuje również stosowanie odmiennych kryteriów oceny działalności tej kategorii przedsiębiorców, a nie jedynie ograniczanie się do kryterium zysku. Zmiana, jaka dokonała się w związku z wejściem w życie ustawy o zawodzie farmaceuty, odnosząca się do zakresu usług i świadczeń zdrowotnych udzielanych przez apteki ogólnodostępne, wzmocniła rolę i zadania apteki jako placówki ochrony zdrowia publicznego, wypełniając lukę w systemie ochrony zdrowia i odpowiadając na jego potrzeby związane $\mathrm{z}$ deficytami personelu medycznego oraz przeciążeniem systemu ochrony zdrowia. Tym samym uzasadnione jest pytanie o to, czy bezpieczeństwo pacjenta $\mathrm{w}$ tym obszarze zostało zapewnione na odpowiednim poziomie.

Słowa kluczowe: apteki; opieka farmaceutyczna; usługi farmaceutyczne; bezpieczeństwo zdrowotne; bezpieczeństwo pacjenta

\section{LEGAL DETERMINANTS OF THE OPERATION OF COMMUNITY PHARMACIES AND PATIENT SAFETY}

\section{Su m m ary}

Granting a pharmacy a special legal status by recognizing it as a public health facility where authorized persons provide pharmaceutical services, as well as a place of pharmaceutical care and professional tasks by pharmacists, places this enterprise in the sphere of significant influence of the state and its authorities. It also requires the use of different criteria for assessing the activity of this 
category of entrepreneurs, and not only limiting ourselves to the profit criterion. The change that took place in connection with the entry into force of the Act on the Pharmacy Profession, relating to the scope of services and benefits provided by generally accessible pharmacies, confirmed the role and tasks of the pharmacy as a public health facility, filling the gap in the health care system and responding to its needs related to shortages of medical personnel and overload of the healthcare system. It is therefore justified to ask whether the guarantees of patient safety have been provided at a satisfactory level.

Keywords: pharmacies; pharmaceutical care; pharmaceutical services; health security; patient safety 